\section{Etapy rozwoju miast typu smart}

\section{Stages of development of smart cities}

Streszczenie

Miasta typu smart są efektem rozwoju technik innowacyjnych i całego sektora badań w zakresie zaawansowanych technologii. Liczne globalne firmy są zainteresowane sprzedażą swoich produktow, ktore są adresowane i przystosowywane do rozwiązań miejskich. Obserwując rozwoj miast inteligentnych wyrożnic można rozmaite etapy wprowadzania produktów zaawansowanych technologicznie do codziennego życia miasta, a z czasem także do kreacji rożnej wielkości załozeń urban stycznych a nawet całych miast. Wprowadzanie tych produktów związane jest takzez zrowdzenymib miejskich i ch ada

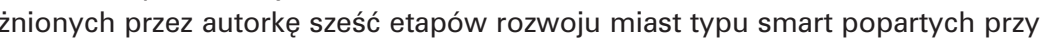
kładami głównie z terenu Europy, oraz ich ilustracjami.

\section{Abstract}

Smart cities are the result of the development of innovative techniques and the entire advanced technology research sector Numerous global companies are interested in selling their products, which are addressed and adapted to urban solutions. By observing the development of smart cities, you can distinguish the various stages of introducing technologically advancities. The introduction of these products is also related to ongoing research in urban communities and their adaptation to take more and newer fix.

The paper will be presented, distinguished by the author of six stages in the development of smart cities supported by examples mainly from Europe, and their illustrations.

\section{Keywords: intelligent city, smart city, spatial planning, development}

Jedynie pomysły ludzkiego umysłu mogą budować miasta. Idea może przekształcić świat i przepisać wszystkie reguty.
Dominick, Dom Cobb, Incepcja

Miasta typu smart są efektem rozwoju technik innowacyjnych i całego sektora badań w zakresie zaawansowanych technologii. Liczne globalne firmy są zainteresowane sprzedażą swoich produktów, które są adresowane i przystosowywane do rozwiązań miejskich'.

Kluczową rolę $w$ tworzeniu miast inteligentnych odgrywa umiejętna implementacja technologii wspierającej rozwó miast $\mathrm{i}$ obsługe mieszkańców oraz tworzenie uniwersalnych przestrzeni miejskich, w których czesto nasze codzienne funkcjonowanie wspomaga nowoczesna technologia². Stąd za inteligentne miasta uważa się takie, w których wykorzystuje się technologie informacyjno-komunikacyjne, dla zwiekszenia interaktywności i wydajności infrastruktury miejskiej oraz jej komponentów mości mieszkańców ${ }^{3}$.

Nicos Komninos 4 uważa, że inteligentne miasto to obszar (miasto, region miasta, struktura zurbanizowana) składający się z czterech elementów:

- kreatywnej populacji realizującej działania intensywnie wykorzystujące wiedze

- efektywnie działających instytucji i procedur tworzenia wiedzy umożliwiających jej nabywanie, adaptację i rozwój, - rozwiniętej infrastruktury szerokopasmowej, cyfrowych przestrzeni, e-usług oraz narzędzi on-line do zarządzania wiedza
- udokumentowanej zdolności do innowacji, zarządzania szy, ponieważ innowacyjność i zarządzanie w warunkach niepewności są kluczowe do oceny inteligencji.

Óśodek badawczy w MIT zajmujący się problematyką smart city definiuje pojęcie miasta inteligentnego jako inteligencje mieszczaca sie w połaczeniu coraz bardziej skutecznych cyfrowych sieci telekomunikacyjnych, wszechobecnie wystepujacej inteligencij, czujnikach i znacznikach i oprogramowanInteligencja ta nie istnieje w oderwaniu od innych systemów miejsich. Przejawi sie on w sieci polaczen do mechaniczmich

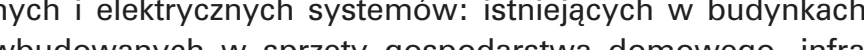

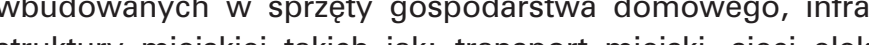
struktury miejsiej takich jak: trade i tryczne, siecizace takich jak: trade i ust miejski, sieci elekmiast $^{5}$

\section{Rodzaje miast inteligentnych}

Wśród miast inteligentnych pojawiają się liczne rodzaje, które określają typologię transformacji, jakiej są poddawane współczesne obszary zurbanizowane w erze rosnącej roli nowoczesnych technologii. Choć sposrod wskazanych poniżej określeń najbardziej popularna jest nazwa smart city, to odnosi się ona często do rozmaitych odmian miasta opartego na wiedzy. Stąd pojawiają się rożne definicje miast, w których wykorzystano nowoczesne technologie cyfrowych do rozwiazywania problemów, współczesnych miast.

Najczęściej pojawiające się $\mathrm{w}$ literaturze określenia dotycza wymienionych tu kilku przypadków, których definicje różnia się zdecydowanie między soba. Zaprezentowane poniżej teoretyczne modele, spełniają określone w definicjach kryteria: - miasto inteligentne, złożone $z$ dwu typów: smart city (miasto inteligentnych rozwiązań),

inteligent city (miasto inteligentnych ludzi),

- digital city (cyfrowe miasto),

- sustainable city (zrównoważone miasto)

- eco city (miasto ekologiczne),

- future city (miasto przyszłości),

- ubiquitous city (miasto wszechobecne),

aerotropolis (miasto połączeń powietrznych).

Każde $z$ tych miast jest określone przez inne kryteria. Jednak współcześnie wiele miast realizuje programy zawarte także $w$ innych modelach opisanych poniżej, więc $w$ rzeczywistości w jednym przykładzie miasta realizowane są dzisiaj liczne dee zawarte we wskazanych powyżej modelach.

Definicje inteligentnego miasta jest rozróżniana w literaturz przedmiotu na miasto inteligentnych rozwiązań (Smart City) i miasto inteligentnych ludzi (Inteligent City). Każde z tych modeli miast jest określane przez co najmniej sześć odrębnych kryteriów6.

Kryteriami okreslającymi smart city są: inteligentna gospodarka; inteligentna mobilność; inteligentne środowisko; inteligentne zarządzanie; srodowisko funkcjonujące dzięki inteligentnym rozwiązaniom; oraz inteligentne warunki życia oparte na inteligentnych urządzeniach. Przykładów tego typu miast jest coraz więcej. W corocznych konkursach na najbar-
Documented capability of innovation, management, and problem solving, which emerge for the first time, because innovativeness in the condtions of uncertainty is of

smart cities, defines the, engaged in the topic of ligence residing in the combination of growingly effective ITC networks, omnipresent intelligence, sensors, markers, and software. This intelligence does not exist in detachment from other urban to mechanisal and electrical systems, present in buildings, embedded in household appliances, urban infrastructure systems, such as public transport, electrical grids, water supply and wastewater disposal pipelines, and methods of protecting the safety of city residents 5 .

Types of smart cities

Amongst smart cities, there are numerous specific ypes, which define the typology of transformatio that contemporary urbanised areas are subjected the growing role of advanced techprovided below is the term 'smart city' less, it frequently refers to different variants of anowledge-based city Hence, here are different definitions of cities making use of advanced digital pchologies so as to solve problems of contemporary cities.

The most common phrases appearing in the subject literature refer to several cases listed herein ences. The theoretical models provided below satisfy the criteria specified in the definitions: - Intelligent / smart city, consisting of two types: - smart city (a city of intelligent solutions), -intelligent city (a city of intelligent people Digital city,

- Eco city,

Ubiquitous city,

Aerotropolis (a city of air connections).

Each of these cities is defined by different criteria. Nevertheless, nowadays many cities implemen agendas which are consed also in other models ple of a city many concepts contained in the above models are implemented today.

The definition of a smart / intelligent city is divided in the subject literature into a city of intelligent solutions (Smart City), and a city of intelligent people (Intelligent City). Each of those models of cities is
defined by at least six separate criteria Crited by at least six separate criteria.

my; smart mobility; smart environment; smart man-
monation agement; environment functioning thanks solutions; and smart living conditions based on smart devices. There are more and more examples
of such cities. In annually organised competitions of such cities. In annually organised competitions for the smartest city in the world, in 2014 Europesmart cities in Europe of today are - among others - Santander, Spain, and Plantr, designed in Portuga Criteria of an intelligent city are as follows: free access to broadband Internet; availability of a wid 
dziej inteligentne miasto świata w roku 2014 dominowały miasta europejskie. Spośród miast typu smart city w Europie dzisiaj jednymi z najbardziej znanych sa między innymi Santander w Hiszpanii i projektowany w Portugalii PlanIT.

Kryteriami miasta inteligentnego (intelligent city) są: darmowy dostęp do szerokopasmowego internetu; dostępnośc szei administracji lokalnej; wysoko wykształcone społeczeństwo, stale sie uczace; otwartość społeczności lokalnej na nowe razwiaz rozwaz spolezniajw wectón lityzm. Pierwszym na świecie miastem projektowanym jako inteligentne było koreańskie Songdo City.

W coroczne prowadzonych rankingach na najinteligentniejsze miasto świata ${ }^{7}$ wybieranych jest kilka miast (od 5 do 10 sze miasto świata
zależnie od firmy).

Dzięki odpowiedniemu know-how, innowacyjnym umiejętnościom i inicjatywie "Smarter Planet”, firma IBM jest zaangażowana w bardziej inteligentne i zrownowazone wykorzystanie przestrzeni życiowej. IBM kontynuuje ich budowę, wspierając nowymi rozwiązzaniami różnorodne projekty. Cyfrowe miasto - digital city, występuje w rozmaitych wersjach. $Z$ jednej strony jest przedstawiane jako nierealna idea miasta, marzenie tworcow istniejące jedynie w cyfrowej rzeczywistości, wygenerowana wizja miasta ze snów, pojawiająca się scenografia w filmach i w grach komputerowych science fiction. Drugim razem mamy do czynienia z projektami miast kreowanymi przez programy cyfrowe. W końcu pierwszej dekady XXI wieku, w perspektywie zwiększającego się zapotrzebowania na budowę miast podjęto próbę usprawnienia procesu budowy i zarzadzania miastem szukajac miejskiego systemu operacyjnego - jednej platformy zarzadzajacej energia, woda, ruchem, bezpieczeństwem i jakimkolwiek innym miejskim systemem

Niektóre projekty nowych miast bedą mogły być zrealizowanektre projekty noźć miast będą mogly być zrealizowawynika z braku materiáów niezbejnych do jego budowy. jak to ma miejsce w przypadku Mega City-Pyramid w Tokio ${ }^{\circ}$.

Ważną rolę w propagowaniu idei miasta cyfrowego odgrywa Korean Society of Basic Design \& Art (KSBDA) organizując coroczne kongresy i wystawy projektów takich miast

Określenie zrównoważone miasto - sustainable city odwołuje się do Raportu Gro Brundtland Nasza Wspólna Przyszłośćn Istnieje wiele definicji rozwoju zrównowazonego, czy równoważenia rozwoju. Dokumenty ONZ określają to zjawisko jako „proces mający na celu zaspokojenie aspiracji rozwojowych obecnego pokolenia, w sposób umożliwiający realizację tych samych dążeń następnym pokoleniom"

Zgodnie z wypracowanymi przez ONZ oraz Unię Europejską standardami, miasta powinny być projektowane w sposób ograniczający do minimum ich negatywne oddziaływanie na srodowisko, z szacunkiem dla lokalnej społeczności, dziedzictwa kulturowego, ale przy uwzględnieniu rachunku ekonomicznego. Prace nad tego typu miastem prowadzone od ponad 30 lat są bogato dokumentowane ${ }^{11}$. range of services on the Internet, including access to libraries and local administration; highly educated constantly learning society; openness of the locad developed system of social participation in the decision-making process regarding goals connected with the city development; and multiculturalism and cosmopolitanism. The world's first city designed as an intelligent city was Songdo City, Korea. Annually held rankings of the smartest city of the world' select several cities $(5$ to 10 , depending on the Corporation)
Thanks to relevant know-how, innovative skills, and the initiative 'Smarter Planet', the IBM corporation is engaged in smarter and more sustainable use of the living space. IBM continues to build them, supporting diversified projects with its new solutions.

Digital city has many different versions. On one hand it is presented as an unrealistic concept of a city; a dream of its creators existing only in the digital reality; a generated vision of a dreamlike city, occurring
on sets of many movies and in science-fiction computer games. Then we can also come across design of cities created by digital software. At the end of the first decade of the 21st century, in the perspective of the growing demand for new cities to be built an attempt at improving the process of building and
managing the city was made, searching for an urba operational system - one platform managing energy water, traffic, security, and any other urban system ${ }^{8}$. Some designs of new cities will be able to be actually implemented only in the future. This delay results from the lack of materials necessary to build them like it is the case with Mega City-Pyramid in Tokyo. a digital city is played by the Kating the concept sic Design \& Art (KSBDA), which orgaises annu congresses and exhibitions of designs of such cities in different parts of the world.

The term 'sustainable city' refers to the Report of Gro Brundland Our Common Future ${ }^{10}$. There are many definitions of sustainable development, or this phenomenon as 'a process aimed to satisfy development-related aspirations of the current generation, without compromising the ability of future generations to achieve the same goals'

According to the standards developed by the UN and the European Union, cities should be designed tive effect on the natural environment, with respect for local communities, cultural heritage, but taking economic calculation into account. Works on such a city carried out for more than 30 years are documented abundantly." Within the scheme of such projects efforts are made to transform dispersed hood communities, with the dominane neighbouan and bike traffic. There are also reports according to which sustainable cities are perfect cities ${ }^{12}$. Nowadays, there are a number of cities being built, designed or reconstructed according to the advocated guidelines of sustainable development of huma ings describing the level of residents' satisfaction for years now, and some of them occupy leading positions in terms of the most expensive location within the area of nearby metropolitan areas Eco-cities started to emerge in the 1970s. Initially,
W ramach tych projektów dązy się do przekształcenia rozprosiedzkie, o dominacji ruchu pieszego i rowerowego. Pojawiaja się także doniesienia określające miasta zrównoważone jako idealne ${ }^{12}$. Powstaje współcześnie szereg ośrodków, zaprojektowanych lub przebudowanych zgodnie z postulowanymi wytycznymi zrównoważonego rozwoju siedzib ludzkich ${ }^{13}$. Ośrodki takie od lat utrzymują sie na najwyższych pozyciach rankingów, opisuiacych zadowolenie mieszkańców, a kilka nich także na listach najdroższych lokalizacji w obrębie pobliskich obszarów metropolitalnych ${ }^{14}$

Miasta ekologiczne-eco city zaczely powstawać w latach 70. XX wieku. Początkowo uważano, że w miastach tych powinna dominować niska zabudowa wznoszona z materiałów naturalnych, odnawialnych lub uzyskanych w wyniku recyklingu, wskazane jest zageszczenie zabudowy dla oszczędności terenu oraz zapewnienie dostepnności do terenów zieleni.

Współcześnie najważniejszymi kryteriami miasta ekologicznego są: samowystarczalność w pozyskiwaniu czystej energi wody; system recyklingu odpadów - układ zero-odpadów likwidacja emisji dwutlenku węgla; zrównoważona mobilność komunikacyjna i transportowa; przywrócenie zniszczonyc ekologicznie obszarów miejskich do użytkowania; mieszkani dla wszystkich grup społecznych; edukacja ekologiczna; zdo ność do wzrostu i rozwoju w miarę zmiany populacji.

Miasto przyszłości - future city jest powszechnie znane z wielu prezentacji artystycznych, w ktorych była to przestrzeń sinie zurbanizowana, zdegradowana, wypełniona instalacjam przemysłowymi, pozbawiona zieleni. Te wizje nie koniecznie są realne. Obecnie wiele ośrodków korzysta z nazwy miasto przyszłości nadużywając tego terminu. Mieszczą się tu miasta inteligentne i ekologiczne. Wśród pomystów pojawiaja się także projekty science fiction zwiazzane $z$ urbanizacja obcych planet jak i z kolonizacja oceanów. Usytuowane na wodzie instalacje mogą odnosić się do:

- pływających miast, które wykorzystają pływalność, aby pozostały w atmosferze planety,

- kolonizacji oceanicznej, związanej z teoria i praktyka budowania struktur umożliwiających ludziom życie na stałe na obszarach Ziemi pokrytej woda

- bardzo dużych konstrukcji pływających, wynikajacy z teore tycznych możliwości dla budowy konstrukcji pływających na morzu.

Kolonizację oceanów być może rozpocznie budowa miasta Artisanopolis, które zostanie otoczone falochronem, przypominającym mury warowni sredniowiecznych i miescić będzie kilka tysięcy mieszkańców ${ }^{15}$. Innym rozwiązaniem są pływajadziesięciu tysięcy osób, jak np. projekt Vincenta Callebauta - Lilypad dla 50 tys. mieszkańców, ksztattem przypominające lilie wodne.

Koncepcja Ubiquitous City (U-City) czyli miasta wszechobecnego zdefiniowano jako miasto, w którym stosuje sie powszechne przetwarzanie danych dla funkcjonowania systemów miejskich jako integrację systemów informacyjnych z systemami społecznymi. Związane jest to z ciągła inwigilacją mieszkanców. Kazde urządzenie i usługa w obrębie mia- it was believed that low buildings made of natural, renewable or recycled materials should dominate such cities, development should be dense so as to free access to green areas. Today, the most in portant criteria of an eco-city are as follows: selfsufficiency in obtaining clean energy and water a waste recycling system - zero-waste; liquidation of the emission of carbon dioxide; sustainable traf fic and transport mobility; restoration of ecologicaly droups; ecological education; a bity to sow cial groups; ecological education; ability to grow
and develop along with changes in population. The future city is broadly known from numerous tistic presentations, where it was a strongly urbanised, degraded space, filled with industrial installations, deprived of greenery. These visions are not necessarily realistic. Currently, many centres use the comprises intelligent cities and eco-cities. Among concepts of future cities there are also science-fiction designs, referting to urbanisation of other planets, as well as to colonisation of the oceans. Installations located on the water may refer to:

- floating cities, which make use of buoyancy so as to remain within the atmosphere of the planet, and practice of building structures enabling peo ple to live in the parts of Earth covered with water - enormous floating structures, resulting from theoretical possibilities of building floating structures on the sea.

Perhaps ocean colonisation will be launched by the construction of a city called Artisanopolis, which defence walls of medieval fortresses and will provide housing for several thousand people ${ }^{15}$. Another solution comprises ecological floating island-cities, intended even for tens of thousands of people, like e.g. the design by Vincent Callebaut - Lilypad The concept of the Ubiquitous City (U-City) has been defined as a city where data processing solutions are broadly used for the purposes of the operation of urban systems in the integration of IT systems with social systems. It is connected with
constant invigilation of residents. Each device and constant invigilation of residents. Each device and service within the city is linked to the IT network,
predominantly via wireless network channels. This coordination between individual components enables to reach better efficiency and synchronisation. The term 'ubiquitous city' is commonly regarded as a clearly Korean concept, and Songdo-City is to be the best model of this phenomenon.

Aetropolis is a model city which is determined by port'16, its significance in the transit and transporting people between cities on one hand, and on the other in linking the city with its region. In light of increased mobility caused by globalisation, the Aerotropolis model advocates the development of for its residents.

Examples of solutions of different types of cities Montpellier, France, is believed to be one of the first smart cities in Europe. This French point
metropolis was furnished with an urban optical 
sta są połączone z siecią informacyjną, głównie przez kanały sieci bezprzewodowych. Ta koordynacja pomiędzy różnymi komponentami umożliwia osiagnięcie większej wydajności i synchronizacji. Określenie "wszechobecne miasto" jes powszechnie uznawane za wyraźnie koreańska koncepcje a Songdo-City ma być najlepszym wzorcem tego zjawiska. Aerotropolis, to model miasta, które jest zdeterminowane infrastruktura dużego międzykontynentalnego lotniska16, jego znaczeniem $w$ tranzycie $i$ transportowaniu ludzi między miastam z jednej strony, a z drugiej z powiazzan miasta z regloniz miasta w oparciu o dostępności jego mieszkańców do skutecznych połączeń.

\section{Przykłady rozwiązań rożnych rodzajów miast}

Za jedno z pierwszych miast inteligentnych w Europie uważa się Montpellier punktowa technopolie francuską, już w latach 90. wyposażone w miejską sieć świattowodową dla umożliwienia rozwoju komunikacji17. Wybranie spośród wielu założeń smart city miasta Santander, położonego w północnej Hiszpanii18, wynika $z$ faktu realizowania $w$ nim międzynarodowego projektu Smart Santander, w którym uczestniczą też inne ośrodki jak np. Belgrad, Guildford, Lubeka. We wszystkich miastach biorących udział $w$ projekcie zainstalowano w sumie dwadzieścia tysięcy czujników, z czego Santander wyposażono w 12 000, wykorzystujących rozmaite technologie loT. Powoduje to, że miasto jest ośrodkiem pilotażowym realizowanego projektu. Celem projektu jest wykorzystanie ośrodka badawczego, środowisk naukowych, użytkowników końcowych i dostawców usług dla opracowania możliwie maksymalnego ograniczenia barier technicznych i społecznych w przekazywaniu informacji o rozmaitych, oferowanych w mieście i regionie usługach oraz szerokiego wachlarza wiadomości, dla mieszkańców i wypoczywaiących, użytecznych w życiu codziennym. Wramach prowadzonych studiów

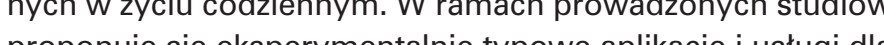
inteligentneg miasta jako banja nad technologiami dla styczna ocene testów ako baptowalnych przez użytkomi i realiPierwsze miasto inteligentne na świecie Songdo-city ${ }^{20} \mathrm{w}$ Korei Poludniowej, zaplanowa Poludniowe, za in prez $\mathrm{km}^{2}$ da 500 tys. ni szkancow jeszcze w XX wieku, przez firmę Koh, Petrsen \&Fox we wspolpracy z Cisco. Jego budowa trwa od początku XXI w. I ma byc zakończona za kilka lat. W projekcie przewidziano wielokondygnacyjne biurowce o funkcji administracyjnej i usługowej usytuowane w wokół centralnego parku nawiązując do nowojorskiego odpowiednika. Wewnąrz niskiejzabudowy apatamentowców usytuowano szkoły i usługi sportowe. Inne uslugi, $w$ tym uniwersytety ${ }^{2}$ powiązano z terenami zieleni, które zajmują $32 \%$ całkowite powierzchni założenia. Miasto stanowi część Specjalnej Strefy Ekonomicznej i jest połączone 21-kilometrowym mostem drogowym z międzynarodowym lotniskiem Icheon.

Wsród wielu nowo realizowanych miast na Dalekim Wschodzie jest ośrodkiem w pełni funkcjonującym ${ }^{22}$.

Rozbudowa lotniska Inchon uzasadnia przywołanie modelu Aerotropolis do Songdo przede wszystkim ze względu na fibre grid for the purposes of facilitating communication as early as in the $1990 \mathbf{s}^{17}$. The fact tha from amongst numerous projects of a smart city Spain ${ }^{18}$, results from the fact that it is a site of im plementation of an internationat Smart santen im project, participated by other cities, such as Belgrade, Guildford, or Lübeck. In all cities participating in the project the total of twenty thousand sensors were installed, 12,000 of which were allocated to Santander, applying different loT technologies. the project. The goal of the project is making of the research centre, scientific circles, final users, and service providers for the purposes of developing the maximum possible reduction of technical and social barriers in transmitting information on diversified services offered in the city and the region and a broad array of news addressed to city
residents and tourists, useful in the everyday life. Within the studies performed, typical application and services for a smart city are proposed to be used experimentally within the scheme of research into specific technologies, along with realistic evaluation of tests acceptable by users

The world's first smart city, Songdo-city, South Koarea of $53.4 \mathrm{~km} 2$ for 500 thousand people already in the 20th century, by Kohn, Petersen \&Fox, in cooperation with Cisco. Its construction has been in progress since the beginning of the 21st centur and is planned to be completed in several years ine. The design features multistoried office build ings with administrative and service functions, lo-
cated around the central park, which correspond to its equivalent in New York. Low-rise apartmen buildings house schools and sports facilities. Other services, including universities ${ }^{21}$, are linked with green areas, which occupy $32 \%$ of the total surface area of the project. The city constitutes a part of a Special Economic Zone and is linked to the inlong road bridge. Amongst many newly-erected cities in the far east, it is a fully operational city 22 . The extension of the airport in Inchon justifies making a reference of the model of Aerotropolis to Songdo most of all due to its geographical location ${ }^{23}$. It allows to increase its communication an economic significance as a centre in the true sense
of the word. The city may contribute to connecting numerous important large cities in the region, such Beijing, Tokyo, Shanghai, and Hong Kong. Songdo-City is also in the process of more and more intensive transformation into a ubiquitou city. Ubiquitous data processing allows to easily energy consumption, traffic. The city as cooper ate with citizens on an individual basis. Children wear bracelets with micro-chips, which makes easier to find them in the city. New technologies of waste disposal has been introduced here, as well. transports it to a treatment plant. Devices installed in water $\mathrm{pip}$ a treatment plant. Devices installed table water and water which is undrinkable. Song do also qualifies to a group of cities dubbed Leaders in Energy and Environmental Design (LEED) fies the strictest enviro jego położenie geograficzne ${ }^{23}$. Pozwala to na zwiększenia jego dziwym tego słowa znaczeniu. Miasto moze przyczynić się do skutecznego połączenia wielu liczących się wielkich ośrodków w regionie, takich jak Pekin, Tokio, Szanghaj i Hongkong Songdo-City coraz bardziej przekształca się także w ośrodek typu Ubiquitous City. Wszechobecne przetwarzanie danych pozwala na łatwe zarządzanie wieloma aspektami miasta, ta kimi jak: bezpieczenstwo, zużycie energii i ruch. Missto może wspótpracować z obywatel wspólpraco wac z oby a tizycie nor W polegające na sieci zasysającej śmieci i transportującej je do oczyszczalni. Zainstalowane w przewodach wodnych urzapicia songdo kwafikje sie takze do grupy mist okje do picia. Songdo kwa odrożiene wie takie do grupy miast okreslanych jako Leadrship in Energy and Environm mizt okesta (LEED), co oznacza, ze spelnia najwyższe normy środowiskowe dotyczące zużycia energii i odpadów.

RMPojekt miasta „Planit Valley" opracowany w latach 2011 2015 na powierzchni $6,7 \mathrm{~km}^{2}$ jest prywatnym, inteligentnym miastem, przeznaczonym docelowo dla 225 tysięcy mieszkanców ${ }^{24}$, Korre ma powstac w Portugalii na wschód od miasta Porto. Idea ta wniknęla z krytyki kopiowania XX wiecznych mias jakie realizowano w Dubaju i w Szanghaju. Jest to modelowe miasto przyszlosci, W projekcie którego wspótpracowały firmy IBM, HP, Microsoft, Panasonic i inne, oparte na wizji programistycznej "Living PlantT" ${ }^{25}$ prezentującej system operacyjny "Uban Operating System" (UOS) w skali realnej ${ }^{26}$. Platforma UOS gromadzi informacje pochodzące z czujnikow umieszczonych w całym mieście, zasilające aplikacje, które monitoruja i kontrolują systemy miasta. Większość aplikacji platformy bedzie dostarczana przez Living PlanIT i jego spótki partnerskie. Fundamenty budynków w mieście wykonane z prefabrykowanych bloków, bẹda wyposażone we wszystkie niezbedne inteligenthe infrastruktury i inteligentne technologie. zainstalowane fabrycznie podobnie jak ściany budynów na rzucie szescioktów. Zrealizowane miasto ma służyć jako żywe laboratorium, tow. Zrealzow che

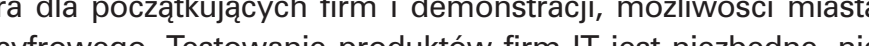

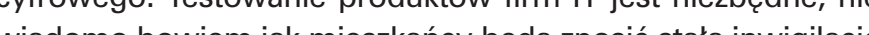
who imonito jest zatwierdzona przez gmine Paredes i zostala uznana przez

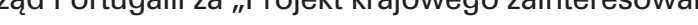

$Z$ powodu trudności finansowych nie rozpoczęto jeszcze jego budowy.

Przy wyborze przykładu miasta zrównoważonego oparto sie na Raporcie Najbardziej Zrównoważonych Miast Świata ${ }^{27}$ Przedstawia on takio, kiore Kozwijają się uwzględniając potrzeby ludzi i środowiska. Kryteria jakie wzięto pod uwage $w$ badaniach dotyczą: jakosci życia mieszkanców, wpływ urbanizacji na środowisko naturalne oraz poziom rozwoju gospodarczego.

W rankingu dominują miasta europejskie ${ }^{28}$. Najwyższa pozycja Frankfurtu wynika z bardzo dobrych wyników w obszarach wpływu na środowisko i potencjału do rozwoju gospo- mental standards pertaining to the use of energy and waste.

The project of a city 'Planit Valley', developed in vate smart city the target population 2 , is a pri(o reach 225 thousand ${ }^{24}$. It is to be constructed in Portugal, to the East from Porto. This concept resulted from criticisms of copying 20th-century cites, erected in Dubai and Shanghai. It is a mode the future, whose design is an effect of cother corporations. It is based on a software vision 'Living PlanlT'25, presenting the Urban Operating System (UOS) in a real scale ${ }^{26}$. The UOS platform collects data coming from sensors placed all over the city, feeding applications which monitor and of the permstems of the city. Most application and its partner will be supplied by Living Plant ings in the city, made from prefabricated elements, will be equipped with all necessary factory-fitted smart infrastructures and smart technologies, and givity is planned to serve as in companies, and a demonstration of the opportunities offered by a digital city. Testing of products of $I T$ corporations is indispensable, as it is impossible to Thents will bear constant invigiliation 政 by the Paredescom. The Planit Valley is approved as a 'project of national interest' by the Portuguese government. Due to financial difficulties, the construction works has not been launched yet.

When choosing an example of a sustainable city, the Report of the World's Most Sustainable Cities of people and of the environment. Criteria which have been considered refer to the quality of life of the residents, the effect of urbanisation on the natural environ The ranking is dominated by European cities ${ }^{28}$. The 作 and the potential of economic development It is predicted that by 2030 the emission of greenhouse gases will have been reduced by $50 \%$, and in 2050 作 city and its residents. In the city there is also Germany's largest municipal park of the total surface of people riding bikes has been growing $(15 \%$ of commuters to work), which is fostered by compact urban development. The city has based its development on the banking sector and numerous IT companies located in the agglomeration and in the region.
Milton Keynes, a extensively developed English
town built in the 1970s, which in 2009 reached the population of 241 thousand inhabitants, is regarded as one of the first eco-cities in Europe. Today there are many towns of the kind, but the desig that could be recognised as the most remarkable 
darczego. Przewiduje się tu do 2030 r. redukcję o 50\% emisji gazów cieplarnianych, a w roku 2050 stuprocentowe wykorzystanie energii ze źródeł odnawialnych dla potrzeb miasta i jego mieszkańców. W mieście znajduje się także największy w Niemczech park miejski, o powierzchni 8 tys. ha. Dodatkowo wzrasta liczba osób korzystających z roweru (15\% dojazdów do pracy), czemu sprzyja zwarta zabudowa miejska. Rozwój gospodarczy miasta oparto na sektorze bankowym i licznych firmach IT znajdujących się w aglomeracji i regionie. Za jedno z pierwszych miast ekologicznych w Europie uważa sie wzniesione w latach 70. XX w, ekstensywnie zabudowane angielskie Milton Keys, które w 2009 roku osiągnęło 241 tys. mieszkańców. Dzisiaj takich miast jest wiele, ale za najbardziej niezwykłe można uznać projekt założenia HavvAda w Turcji, usytuowanego na sztucznej wyspie, która powstanie z materiału skalnego uzyskanego w czasie realizacji nowego kanału łączącego Morza Marmara i Czarne. Wyspa zaprojektowana przez architekta Dror Benshetrit w roku 2012 będzie samowystarczalna energetycznie. Projekt zakłada ukształtowanie powierzchni wyspy z sześciu kopulastych wzgórz o wysokości od 230 do $400 \mathrm{~m}$., pokrytych zielenią. Układ urbanistyczny wyspy tworzą te właśnie kopuły wykonane z lekkiej konstrukcji. W ich wnętrzu znajdą się przestrzenie publiczne miasta z usługami. W ścianach kopuł znajdą się mieszkania, biura i administracja, szkoły oraz inne usługi, Miasto przeznaczono dla 300 tys. mieszkańców. HavvAda Island będzie uzyskiwać energię z wiatru i słonca. Woda deszczowa, odpowiednio przygotowana ma służyć celom bytowym, a woda morska do chłodzenia przeszklonych pomieszczeń. Dzięki oczyszczaniom i filtrom miasto ma być neutralne dla środowiska.

Miasto przyszłości - Artisanopolis zaprojektowane przez Instytut Seasteading ${ }^{29}$, jako pływająca wyspa na oceanie, ma być zbudowana z pojedynczych, połączonych ze soba elementów, które bẹda unosić się na powierzchni wody. Bloki te swobodnie moga być przemieszczane w inną czesć miasta Konstrukcie tego typu z uwagi na zabezpieczenie przed wa runkami klimo typu, z uwagi na zabezpiecź cé pred waW celu zapewcieni sazewidzina ográci zaprojektowan. szk uni do uprawy żywosci. Woda stodka ma pochedzic z odsolone i uzda zionej, a energię będa przewiduc icze eje

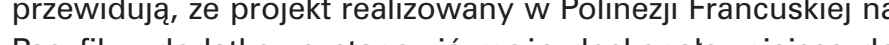
Pacyfiku, dodakowo stawic testowania nowych metod rolniczych oraz alternatywnych sposobów zarządzania.

\section{Podsumowanie i zakończenie}

W Europie proces wprowadzania nowych technologii rozpoczął się w latach 70. XX w. od osadzenia się firmy MBI w regionie Montpellier. Rozwój przestrzeni technopolialnych początkowo zlokalizowanych na peryferiach powoli wkraczał do miast oferując coraz nowsze produkty dla jego mieszkańców i władz miejskich ${ }^{30}$. Dzisiaj poprzez smartfony i aparaty telefoniczne $w$ naszych kieszeniach do czujnikow na latarniach miejskich, w chodnikach i kanałach oraz przystankach komunikacji publicznej, współczesne miasto przeniknęło sieciowa technologią informacyjną. of them is the design of HavvAda, Turkey, located on an artificial island, which will be made of rock material obtained during the execution of a can island, designed by an architect name lack Sea. The island, designed by an architect named Dror Ben-
shetrit in 2012, will be energy self-sufficient. The design involves forming the surface of the island as six dome-like $230-400 \mathrm{~m}$ tall hills covered with greenery. The urban layout of the island is formed by the domes made of a light structure. Inside, there will be public spaces of the city with relevant services. The walls of the domes will house schools, and other services. The city is intended for 300 thousand people. HavvAda Island shall be getting energy from wind and the sun. Rainwater, after appropriate treatment, is to be used as household water, and seawater is to cool down glazed premises. Thanks to wastewater treatment plants and environment.

The future city - Artisanopolis designed by Seasteading Institute ${ }^{29}$ as a floating island on the ocean is planned to consist of individual interlinked elements, which will float on the surface of the wate anose blocks will be able to be moved freely to structures need to be protected against climatic conditions, they will be surrounded by breakwaters. Greenhouses allowing to grow food have been designed so as to secure self-sufficiency of the city. Potable water will derive from desalte and treated seawater, and energy will be provide designers envisage that the project implemented in French Polynesia on the Pacific Ocean will additionally constitute a perfect place for testing new farming methods and alternative management systems.

\section{Summary and conclusio}

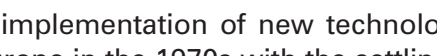
of the MBI Corporation in the region of Montpellie. Development of technopolises, initially located in the suburbs, started to gradually enter territories of cities, offering newer and newer products for its inhabitants and authoriles". Today via smartphones ments and canals, on public transport stops, the contemporary city is permeated with the IT network technology

When observing the development of smart cities, one could distinguish stages of introducing technologically advanced products to the everyday life, different sizes, and even entire citios. first stage is the period of nies in the vicinity of the city, creating parks and technological poles, which resulted in the growth of the regional GDP.

In the second stage, also upon the initiative of different associations, with the participation of loca with the more and more intensive use of new technologies for the purposes of their functioning. Boosting the application of the most advanced
technologies in the city management fosters the in-
Obserwując rozwój miast inteligentnych wyróżnić można etanie do codziennego życia, a z czasem także do kreacji różnej wielkości założeń urbanistycznych a nawet całych miast. Za pierwszy etap można uznać okres osiedlania sie firm IT w regionie miasta, kreowanie parków i biegunów technologicznych, co owocowało wzrostem regionalnego PKB.

$W$ drugim etapie, czesto z inicjatywy różnych stowarzyszen, z udzilem whadz lokalnych czy regionazh nastepuje przebudowa miasta technologii do jego fun większym wy

Zwiekszenie korzystanie z najnowszych technologii do zarzadzania miasta sprzyja wprowadzaniu modelu Smart City, technopolie proponuja na swym obszare tego typu rozwazania, co można uznać za trzeci etap tworzenia miast typu smart. Zwiększona ilość rozwiązań IT wymaga przystosowania mieszkańców do ich stosowania stąd pojawiają się living labs, co jest czwartym etapem

Promowanie na przełomie pierwszych dekad XXI wieku przez przedsiebiorstwa takie jak IBM, Siemens i Cisco Systems, wizii diębiorstwa takie jak IBM, Siemens i Cisco Systems, wzi "inteligentnego miasta "Wraz z pelnym programem jego budowy n. UOS stanowi piąty etap rozwoju miasta inteligentnego, w ktorym ta technologia może byc w rożnym zakresie wykorzystywana przez miejskiego administratora bez wiedzy i kontroli mieszkańców.

Za szósty etap można by uznać czas, gdy swiadomi pożytków szkód mieszkańcy miast wskażą i przyjmą zakres rozwiązan IT niezbędnych do sprawnego funkcjonowania miasta. Czy to jednak kiedykolwiek nastąpi?

PRZYPISY

Np. Facebooki Google dysponuja informacjami spotecznymi i informaciami op-
artymi na wiedzy; Apple i Samsung w zakresie produkcij smartfonów i tabletów artymi na wiedzy; Apple i Samsung W Zakresie produkcji smartfonówi itabletón
a takize urzadzen oraz sposobów przedstawiania informaciji, a Fujitsu, IBM oraz

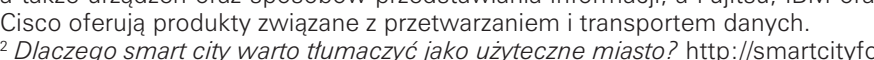
2 Dlaczego smart city wart
rum.jl, dostep 23.04 .2017
3 S Smart Cities Study: Inter

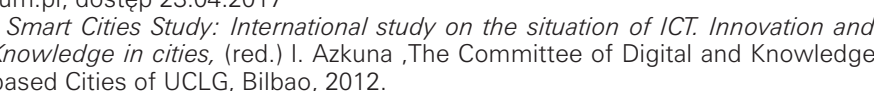
W. Komninos, Intelligent Cities and Globalisationof Innovation Networks. N. Komninos, Intelligent Cittes 2 and
don and New York Routledge 2008 .
sW Mitchell, lntelligent citites, W. Mitchell, Intelligent cities, e-Journal on the Knowledge Society, 2007 .
6 Podstawowe kryteria dla tego typu miast zostaty okresslone przez firmy nujace corocznych ocen rankingowych zgtoszonych miast jak np. ICF założone

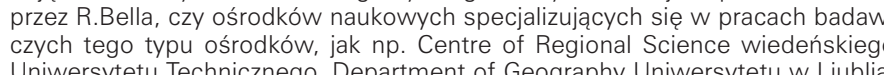
Uniwersytetu Techniczzego, Department of Geography Universyttetu w L Lublia Technicznego w Delft, które w październiku 2007 roku przedstawity ranking 70 Organizowane są przzz róże

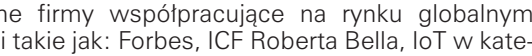
oriach the Smartest City i The Most Inteligent City.
Wypowiedż z roku 2012 bytego prezesa Sony Nobuyuki Ito za: G. Lindsay Miasto w chmurze: Living PlanIT definiuje miasta joko oprogramowanie. https://
www.fastcompany.com o Projekt Pyramid City $w$ Tokio autorstwa Firmy Shimizu za: https://anarchytects.
wordpress.com. $2012 / 12 / 22 /$ tokyo-mega-pyramid-project-the-future-of-cities

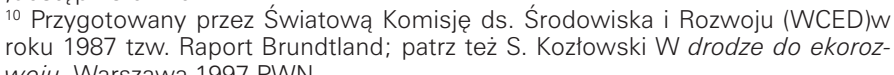
'Warte odnotowania sa zas

ki CNUU, cory w wramaach Habitat
${ }_{12}$ Miasto idealne - miasto zró

Miasto idealne - miasto rrównoważone. Planowanie przestrzenne terenó
zurbanizowanych $\mathrm{i}$ jego wpływ na ograniczenie skutków zmian klimatu A. Kalinownska, Uniwersyteckie Centrum Badan nad Srododowiskiem Przyrodn troduction of the Smart City model. Technopolises propose such solutions, as well, which could be regarded as the third stage of creating smart cities. ing residents to their use; hence living labs, which constitute the fourth stage.

Promoting the vision of a smart city in the first decades of the 21st century by such corporation as IBM, Siemens, and Cisco Siemens, along with a full programme of its construction, e.g. UOS constitus the finh istage of the development of diversified extents by the municipal administrato without the knowledge and control on the part of the city residents.

The sixth stage could be the time when city residents, aware of the benefits and damages, will determine and approve a scope of IT solutions necever happen at all...?

ENDNOTES:

E.g. Facebook and Google possess social information and
knowledge-based information; Apple and Samsung in the scope of production of smartphones and tables, as well as
information display devices and methods, and Fujitsu, IBM, and Cisco offer products connected with data processing

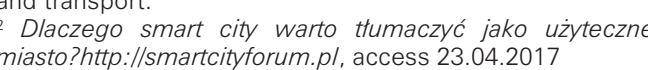
3. Smart Cities Study: International study on the situation of
ICT. Innovation and Knowledge in cities, (ed.) I. Azkuna,
Committee of Digital and Knowledge-Based Cities of UCLG Bilbao, 2012 . Intelligent Cities and Globalisation of I Inn -
N. Komninos,
vation Networks London and New York, Routledge 2008 . W. Mitchell, Intelligent cities, e-Journal on the Knowledg
Society, 2007 . 作 corporations which perform annual ranking assessments
of applying cities, such as e.g. ICF established by R. Bell, centres, such as e.q. the Centre of Regional Sciens of of the
con Technical University in Vienna, Department of Geography of the University in Ljubljiana, Research Institute for Housing,
Urban and Mobility Studies Technical University in Delftt
which in October 2007 presented a ranking of 70 European which in October 2007 presented a ranking of 70 Europead
medium -sized cities 7They are organised by different companies cooperating on
the global market with digital corporations, such as Forbes
ICF Roberta Bella, IOT in categories of the Smartest City and the Most Intelligent City.
8 Statement of former CEO of Sony, Nobuyuki Ito in 2012 ,
after: G. Lindsay, Miasto w chmurze: Living PlanIT definiuje miasta joko oprogramowanie. https://Mww.fastcompany.com
9
9 Design of Pyramid City in Tokyo by Shimizu after: https: anarchytects. Wordpress.com. 2012/12/22/ toky-mega
-pyramid-project-the-future-of-cities/, access on 23.04.2017 10 Drawn up by the World Commission for Environment and
development (WCEDD in 1987, the so-called Brundtland
Relow Report; see also: $\mathrm{S}$,
Warsaw 1997 PWN

"The principles developed by the Congress of New Urba-
nism (CNU), or within the scheme of Habitat, are worth atention in this respect.
2 'Missto idealne przestrzenne terenów zurbanizownanych i jego wo wpły nu na Graniczenie skutków zmian klimatu'. E. E. A. Kalinowska,
University Centre for Environmental Studies and SustainaExamples of the irmplementation of this concept are e.g
Hammarby Siostad - a district of Stockholm Kirchsteigfeld in Potsdam, Vauban in Germany, or Curitiba, Brazili. In the
United States several hundred projects making use of the Sinciples of New Urbanism have been implemented, with
Seaside, Florida (designed by D. Plater-Zyberk). In the Un ed Kingdom projects like that include a new district of Dor
chester, Poundbury, designed by Leon Krier, and built und the patronage of Prince Charles. 
13 Przykładami realizacji tej koncepcji to m.in. dzielnica Sztokholmu Hammarby Sjostad, Kirchsteigfeld w Poczdamie, Vauban w Niemczech, czy brazylijska Kurytyba. W Stanach Zjednoczonych powstało kilkaset projektów wykorzystujących założenia Nowej Urbanistyki w tym położone na Florydzie Seaside (proj. D. Plater-Zyberk). W Wielkiej Brytanii za takie należy uznać nową dzielnicę Dorchester, Poundbury, zaprojektowaną przez Leona Kriera, a realizowana pod patronatem księcia Karola.

${ }^{14} \mathrm{~W}$ Polsce pierwsza zrównoważona dzielnica jest realizowana w Siewierzu - Jeziornej nad Zalewem Przeczycko-Siewierskim na terenie Metropolii Śląskiej.

${ }^{15}$ Prace związane z realizacja tego przedsięwzięcia prawdopodobnie się zaczna w ciagu kilku lat za: www.polsatnews.pl., dostęp 19.01.2017.

${ }^{16}$ Historycznie porty lotnicze zostały zbudowane w znacznej odległości od centrów miast i były nieco uciążliwe, a wartości nieruchomości spadały znacząco w pobliżu lotniska.

$17 \mathrm{~W}$ połowie lat 80. XX w. w Montpelier z inicjatywy okregu miejskiego, regionu Langvedoc-Roussillon i uniwersytetów powstało Stowarzyszenie Montpellier L.R. Technopolie dla stymulowania rozwoju regionalnego poprzez wzrost zatrudnienia, modernizację produkcji, waloryzację potencjału naukowego i technicznego, co wpłynęło na wykreowanie nowej ery urbanizacji miasta.

${ }^{18}$ Miasto liczy ponad 200 tys mieszkańców, jest portem morskim i kąpieliskiem odwiedzanym przez turystów jako popularny ośrodek letni.

19 Podczas sesji RWI Future Internet Assembly w Pradze na początku 2009 roku zidentyfikowano główne wymagania dotyczące rzeczywistej platformy eksperymentalnej IOT.

${ }^{20}$ Znane też jako New Sondo City, Songdo International Business District (SIBD)

${ }^{21}$ W roku 2014 w mieście zainicjowały swą działalność filie czterech uniwersytetów amerykańskich

22 Liczba ludności w ciagu ostatnich 11 lat wzrosła ośmiokrotnie, w IFZ osiedliło się 75 przedstawicielstw międzynarodowych koncernów i firmy z 15 krajów,

${ }^{23}$ Jedna trzecia populacji świata znajduje się w odległości trzech i pół godziny lotu od lotniska Incheon.

${ }^{24}$ Powierzchnia miasta i proponowana liczba ludności ujawnia, że miasto będzie bardzo intensywnie zabudowane, tak, że będzie tu większe zagęszczenie niż w Bombaju, Kalkucie, Karaczi czy Lagos. Za: A. Greenfield, Against Smart City. New York 2013

${ }^{25}$ Pomysł Steve'a Lewis'a i Malcolma Hutchinsona i byłych pracowników IBM.i Microsoft. Założeniem było zbudować prototyp inteligentnego, zielonego miasta w Portugalii, który może być wykorzystany na całym świecie.

${ }^{26}$ UOS to modułowa, inteligentna platforma miejska, którą Living Planit ma nadzieje sprzedać w Chinach i Indiach dla budowy nowych miast. Za: M Angelidou, Smart City Strategy: Plan/T Valley Portugal) http://www.urenio. org. dostęp 15 luty 2016

27 Arcadis Sustainable Cities Intex 2015, w którym objęło badaniem 50 miast z 31 krajów na świecie. Przy opracowywaniu raportu korzystano z danych m.in. ONZ, Banku Światowego, Światowej Organizacji Zdrowia, Międzynarodowej Organizacji Pracy i wielu innych. https://www.arcadis.com.

${ }^{28}$ Wśród pierwszych dziesięciu miast znajduje się siedem ośrodków europejskich i tylko trzy z Azji. Sa nimi: Frankfurt, Londyn, Kopenhaga, Amsterdam, Rotterdam, Berlin i Madryt oraz Seul, Hong Kong i Singapur. Ibidem ${ }^{29}$ Instytut zatrudnia m.in architektów, biologów i działaczy na rzecz ochrony środowiska

30 Wspomniany przykład Montpellier, czy podobne działania stowarzyszenia SICIVAL w Tuluzie

\section{LITERATURA}

[1] Angelidou M... Posted in Intelligent/Smart Cities Strategies http://www. urenio.org/2015/01/26/smart-city-strategy-planlt-valley-portugal/

[2] Eccles, RG, Edmondson, AC, Thyne, S., i Zuzul, T., Książka robocza Living

Plan/T, Harvard Business School 2013

[3] Greenfield A., Against the Smart City, New York 2013

4] Mitchell W., Intelligent cities, e-Journal on the Knowledge Society, 2007.

[5] Komninos N., Intelligent Cities and Globalisation of Innovation Networks,

London and New York, Routledge 2008.

[6] Lindsay, G. Miasto w chmurze: Living Plan/T definiuje miasta jako oprogramowanie. Strona internetowa https://www.fastcompany.com

[7] Strona internetowa https://www.mcgill.ca/channels/news/ubiquitous-city--songdo- $\square \square-236653$

[8] Wdowiarz-Bilska M., Od miasta naukowego do smart city. From science city to smart city. .Czasopismo Techniczne 1-A/2/2012 s. 305-314

[9] Wdowiarz-Bilska M., Concept of the city in the ag of knowlegdes-based eonomy. Idea miasta w kontekście rozowju gospodarki opartej na wiedzy. Czasopismo Techniczne 12-A/2015 s. 223-239

[10] Wẹcławowicz-Bilska E., Miasto przyszłości-tendencje,koncepcje, realizacje. The city of the future - trends, concepts, implementation. Czasopismo Techniczne $1-A / 2 / 2012$ z.1 s. 323-342
${ }^{14}$ In Poland the first sustainable district is being implemented in Siewierz-Jeziorna on Przeczycko-Siewierski Lake within the territory of the Silesian Metropolis.

${ }^{15}$ Works relating to the implementation of this project will be probably launched within several years; after: www.polsatnews. pl., access on 19.01.2017.

16 Historical airports were built quite far from city centres and were a bit burdensome, and the values of properties would drop drastically near airports.

17 In mid-1980s in Montpelier the Montpellier L.R. Technopolie Society was established upon the initiative of the metropolitan district for the purposes of stimulation of regional development by employment increase, production modernisation, valorisation of the scientific and technical potential, which had its effect on the creation of a new era of urbanisation of the city.

18 The population of the city is over 200 thousand people. The city is a sea port and a resort visited by tourists as a popular summer destination.

${ }_{19}$ During the session of RWI Future Internet Assembly in Prague held in the beginning of 2009 the main requirements pertaining to the experimental platform IOT were identified.

${ }^{20}$ Also known as New Sondo City, Songdo International Business District (SIBD)

${ }^{21}$ In 2014 branches of four American universities launched their activities in the city.

22 Over the last 11 years the population rose 8 times; 75 branches of international corporations and companies from 15 countries located their services in IFZ.

${ }^{23}$ One third of the world's population stays within the distance of a 3.5-hour flight from the airport in Incheon.

${ }^{24}$ The surface area of the city and the population proposed reveals that the city will be very intensely developed, so that its density will be higher than in Mumbai, Calcutta, Karachi, or Lagos. After: A. Greenfield, Against Smart City. New York 2013

${ }^{25}$ Idea of Steve Lewis and Malcolm Hutchinson and former employees of IBM and Microsoft. The plan was to build a prototype of a smart, green city in Portugal, which could be applied all over the world.

${ }^{26}$ UOS is a module-based, smart urban platform, which Living Planit hopes to sell in China and India for the purposes of building new cities. After: M. Angelidou, Smart City Strategy: PlanIT Valley Portugal) http://www.urenio.org. access on 15 February 2016.

27 Arcadis Sustainable Cities Index 2015, which covered 50 cities from 31 countries in the world. The report makes use of data from e.g. UN, World Bank, World Health Organisation, International Labour Organisation, and many more. https://www.arcadis.com.

${ }^{28}$ Amongst the first ten cities there are seven European cities and only three cities from Asia. These are: Frankfurt, London, Copenhagen, Amsterdam, Rotterdam, Berlin, and Madrid, as well as Seoul, Hong Kong, and Singapore. Ibidem.

29 The Institute employs e.g. architects, biologists, and environmental protection activists.

${ }^{30}$ The aforementioned example of Montpellier, or similar activities carried out by the SICIVAL society in Toulouse.

\section{BIBLIOGRAPHY}

[1] Angelidou M., Posted in Intelligent/Smart Cities Strategies http://www.urenio.org/2015/01/26/smart-city-strategy-planlt-valley-portugal/

[2] Eccles, RG, Edmondson, AC, Thyne, S., i Zuzul, T., Książka

robocza Living PlanIT, Harvard Business School 2013

[3] Greenfield A., Against the Smart City, New York 2013

[4] Mitchell W., Intelligent cities, e-Journal on the Knowledge

Society, 2007

[5] Komninos N., Intelligent Cities and Globalisation of Innovation Networks, London and New York, Routledge 2008.

[6] Lindsay, G. Miasto w chmurze: Living PlanlT definiuje miasta jako oprogramowanie. Website https://www.fastcompany.com [7] Website https://www.mcgill.ca/channels/news/ubiquitous-city-songdo- -236653

[8] Wdowiarz-Bilska M., Od miasta naukowego do smart city. From science city to smart city. Czasopismo Techniczne 1-A/2/2012 pp. 305-314

[9] Wdowiarz-Bilska M. Concept of the city in the ag of knowlegdes-based eonomy. Idea miasta $w$ kontekście rozowju gospodarki opartej na wiedzy. .Czasopismo Techniczne 12-A/2015 pp. 223-239

[10] Węcławowicz-Bilska E.,Miasto przyszłości-tendencje,koncepcje, realizacje. The city of the future - trends, concepts, implementation. Czasopismo Techniczne 1-A/2/2012 V.1 pp. 323-342 